\title{
AZ AGRÁRKÉPZÉSI SZAKOK NÉPSZERÜSÉGÉNEK ALAKULÁSA A MAGYAR FELSŐOKTATÁSBAN 2019-IG
}

\author{
FINTA ZITA \\ PALKOVICS ANDRÁS \\ KÖSZEGI IRÉN RITA
}

\section{Összefoglalás}

Magyarországon a mezögazdasági foglalkoztatottak iskolai végzettsége kedvezötlenebb képet mutat mind a többi nemzetgazdasági ágazatban dolgozók iskolai végzettségéhez, mind pedig az Európai Unió (továbbiakban: EU) átlagához viszonyitva. Az egyéni gazdaságok vezetői, jellemzöen az idősebb korosztály gyakran szakirányú végzettség nélkül, gyakorlati tapasztalatokra támaszkodva kezdtek mezögazdasági tevékenységbe. A KSH 2012-es felmérése szerint a gazdaságvezetők mindössze 14\%-ának van szakirányú iskolai végzettsége és ennek töredéke, kb. 20\%-a rendelkezik felsöfokú mezőgazdasági végzettséggel. A mezögazdasági foglalkozásúakra jellemzö, hogy minél magasabb az iskolai végzettségük, annál kisebb a valószinüsége annak, hogy a foglalkoztatott tartósan a mezögazdaságban keres megélhetést. Ennek oka többek között azzal magyarázható, hogy a nemzetgazdaság átlagától jelentösen elmarad a mezögazdasági átlagkereset, mindemellett egyre kevesebb a kiegészitö jövedelemszerzési lehetöség. További probléma a foglalkoztatottak elöregedö korszerkezete, a mezögazdaságban dolgozók elöregedö korstruktúrája, a mezögazdaság népszerütlensége a fiatalok körében. Hazánkban az EU-s átlaghoz hasonlóan magas az idös és alacsonyabb a fiatal korosztályhoz tartozók gazdálkodók aránya, azonban a gazdaságméret növekedésével jellemzöen javuló korszerkezet figyelhetö meg. Munkánkban a felvi.hu adatainak segítségével azt vizsgáljuk, hogy hogyan változott a fiatalok felsöfokú mezögazdasági szakirányú végzettség iránti igénye, milyen tendenciát mutat az agrárképzések iránti érdeklödés 2001-töl kezdve. Irodalmi áttekintésünkben kitérünk a mezögazdaságban foglalkoztatottak számának alakulására, az agrártársadalom elöregedö korszerkezetére, a fiatal gazda kérdés fontosságára és a mezögazdaságban dolgozók iskolai végzettségére, melyek a magyar agrárium legfontosabb és legégetőbb problémáit jelentik.

Kulcsszavak: agrárképzés, agrárfelsöoktatás népszerüsége, fiatal gazdák, elöregedö korstruktúra, mezögazdasági foglalkoztatottak

JEL kód: $Q 19$ 


\title{
THE DEVELOPMENT OF POPULARITY OF AGRICULTURAL FACULTIES IN THE HUNGARIAN HIGHER EDUCATION UNTIL 2019
}

\begin{abstract}
Education of agricultural employment in Hungary is less favoured than the education of other industries' employment as well as the European Union (EU) average. Older managers of the individual farms usually started doing agricultural activity and relied on practical experiences in the absence of any specialized studies. According to the Hungarian Central Statistical Office only 14\% of farm managers have specialized studies and $20 \%$ of them have higher agricultural education (2012). Experience suggests that the higher the education of agricultural employees, the less likely that they earn a living in the agricultural sector permanently. It is linked to the fact that the average wage in the agriculture is significantly lower than the national average wage. Moreover additional income opportunities are less and less. Other difficulties are the ageing age structure of the agricultural employees and the unpopularity of agriculture among the young people. The rate of older farmers is higher and the rate of younger farmers is lower in Hungary than in the EU. Although age structure usually improves as the farm size grows. In our study we examine how changes the need of young people for higher agricultural education and what tendency is shown towards agricultural trainings from 2001. We carry out our study using data of www.felvi.hu. In the literature review we discuss the number of agricultural employment, the ageing age structure of the agricultural society, the important issue of young farmers and the education of agricultural employment, which problems are the most important and most serious ones of the Hungarian agriculture.
\end{abstract}

Keywords: agricultural training, popularity of agricultural higher education, young farmers, ageing age structure, agricultural employment

\section{Bevezetés}

\section{A téma aktualitása}

Európa demográfiai helyzetére jellemző a korösszetétel erőteljes megváltozása. A népesség egyre idősebbé válik, elsősorban a tartósan alacsony termékenység és a növekvő várható élettartam következtében. Az elöregedő népesség részben maga után vonja a gazdatársadalom elöregedését is, ami Európa szerte, így Magyarországon is egyre kiemelkedőbb probléma. Az Európai Unióban a mezőgazdasági termelők egyharmada 65 év feletti és több mint $50 \%$-uk átlépte az 55 éves életkort. Ezzel szemben a 35 év alatti gazdálkodók aránya csupán alig 6\%, mely azt mutatja, hogy nem zajlik megfelelő ütemben a generációváltás, öregszik a gazdatársadalom. A probléma súlyosságát jelzi, hogy Magyarországon a 2000-es években felmért adatok szerint a 35 évnél fiatalabb mezőgazdasági dolgozók arányát még 20\% körülire becsülték, az általuk hasznosított mezőgazdasági terület pedig 12\%-ot tett ki. Az évezred küszöbén egy 35 év alatti gazdálkodóra, három olyan gazda jutott, aki betöltötte a 65 . életévét. 2010-ben ez a szám már négy főre, míg 2013-ban már közel ötre növekedett. Magyarország az aktuális adatok szerint az EU-hoz hasonló képet mutat, ahol szintén alacsony, 6,1\% a 35 év alatti gazdák aránya. Az elöregedő agrártársadalom mellett másik kiemelkedő probléma, hogy Magyarországon a mezőgazdasági foglalkoztatottak iskolai végzettsége kedvezőtlenebb képet 
mutat mind a többi nemzetgazdasági ágazatban dolgozók iskolai végzettségéhez, mind pedig az EU átlagához viszonyítva. Az egyéni gazdaságok vezetői, jellemzően az idősebb korosztály gyakran szakirányú végzettség nélkül, gyakorlati tapasztalatokra támaszkodva gazdálkodik. A KSH 2012-es felmérése szerint a gazdaságvezetők mindössze 14\%-ának van szakirányú iskolai végzettsége és ennek töredéke, kb. 20\%-a rendelkezik felsőfokü mezőgazdasági végzettséggel. A mezőgazdasági foglalkozásúakra jellemző, hogy minél magasabb az iskolai végzettségük, annál kisebb a valószínüsége annak, hogy a foglalkoztatott tartósan a mezőgazdaságban keres megélhetést. Ennek oka többek között azzal magyarázható, hogy a nemzetgazdaság átlagától jelentősen elmarad a mezőgazdasági átlagkereset, mindemellett egyre kevesebb a kiegészítő jövedelemszerzési lehetőség. Az EU-hoz 2004-ben csatlakozott kelet-közép-európai tagállamok vidéki térségeiben azonban a mezőgazdasági termelés továbbra is megkerülhetetlen a lakosság megélhetése szempontjából [HERMAN et al., 2018].

\section{Foglalkoztatás a magyar mezögazdaságban}

Magyarországon a mezőgazdaság vidéki foglalkoztatásban betöltött szerepének visszaesése évtizedek óta megfigyelhető. Természeti adottságaink kiválóak az agrártermeléshez, azonban a mezőgazdasági foglalkozásokat a pályaválasztás előtt állók nem szívesen választják, mert nem sorolhatók a divatosnak mondott szakmák közé [KSH, 2015]. A mezőgazdasági népességszámban bekövetkező csökkenés azonban nem újkeletü, mert a csökkenés egyik legjelentősebb hulláma már a hatvanas években jelentkezett. Az 1948 és 1967 között lezajlott kollektivizálás következtében körülbelül 300 ezren hagyták el a mezőgazdaságot és máshol, más szektorokban kerestek megélhetést. A rendszerváltással megalkotott kárpótlási, privatizációs és szövetkezeti törvények változást okoztak a tulajdon-, a földhasználati viszonyokban, melyek kihatottak a gazdálkodási formákra és a mezőgazdasági foglalkoztatottak számának alakulására is [HANTOS, 2010]. Az aktív keresők száma a mezőgazdaságban 1980-ban még 1 millió fö körül mozgott (a nemzetgazdaság aktív keresőinek 19\%-a), de 1990-re ez a szám már 700 ezerre csökkent (15,5\%). Ennek oka a melléküzemágak felszámolásával és a külföldi piac beszükülésével, elvesztésével magyarázható [POPP, 2014]. A mezőgazdaság munkaerő-felhasználásának csökkenése a modern technológiák alkalmazásának és térnyerésének, a termelési szerkezet egyszerüsödésének, a specializációnak, a gazdaság más ágazataiban jelentkező magasabb jövedelemnek és a kedvezőbb munkakörülményeknek köszönhető [DÓZSA, 2017]. A mezőgazdaság vidéki foglalkoztatásban betöltött szerepének visszaesése mellett a szolgáltató szektor térnyerése nemzetközi szinten és Magyarországon is jellemző. Az élőmunka-felhasználás csökkenését eredményező rendszerváltozás utáni gazdasági és társadalmi változások, az új technológiák alkalmazása, a termelési szerkezet leegyszerüsödése, a specializáció és a koncentráció mellett elsősorban a nemzetgazdaság más ágazataiban elérhető magasabb jövedelmek és a kedvezőbb munkakörülmények gyorsították fel a mezőgazdaságból történő munkaerő-kiáramlást [BIRÓ RÁCZ, 2014]. Egyetértünk a Biró és Rácz (2014) szerzőpáros, valamint Dózsa (2017) véleményével, miszerint a foglalkoztatásban bekövetkező térvesztése ellenére a vidéki megélhetés egyik alapvető forrása lehet továbbra is a mezőgazdaság.

A foglalkoztatottság csökkenése mellett a fejlett országokban a bruttó hazai termék (GDP) részesedése is folyamatosan csökken, mindemellett a szolgáltatási szektor súlyának növekedése volt megfigyelhető. A mezőgazdaság részesedése a GDP- előállításból 1989-ben még 13,7\% volt, mely 2009-re 3,7\%-ra mérséklődött [KOVÁCS, 2010]. A KSH 2018-ban végzett gazdaságszerkezeti összeírása alapján a mezőgazdaság már csak 3,6\%-kal járult hozzá a bruttóhazai termék (GDP) termeléséhez. A bruttó hozzáadott értékből 4,3\%-ot adott az agrárium, a beruházásokban $4,1 \%$, a foglalkoztatásban $4,8 \%$ volt az aránya [KSH, 2018]. 


\section{Elöregedö (agrár)társadalom}

A mezőgazdaságban foglalkoztatottak minősége a korösszetétel és az iskolai végzettség szintje alapján jellemezhető [KAPRONCZAI, 2007].

Az öntörvényü demográfiai folyamatok egyik jelensége a korösszetétel változása. A 19-20. században jelentkező demográfiai átmenet a korösszetételre is hatással volt. A korstruktúra radikális átalakulását nevezzük a népesség öregedésének, mely napjainkra a fejlett országokban megfigyelhető. A népesség öregedése az időskorúak össznépességen belüli arányának emelkedését értjük, mely általában együtt jár a fiatalok arányának csökkenésével [KSH, 2004].

Az EUROSTAT értelmezésében a 0-19 éveseket fiatalnak, míg a 60. év felettieket idősnektekinti. Az öregedés folyamatában az idősek, a fiatalok, az aktív korúak száma és aránya is változik, mely az egész korösszetételre hatással van, a korfa, mely a népesség korstruktúráját mutatja, megnyúlik. Ha az öregedés folyamata elörehaladott, akkor a fiatalok számát meghaladja az időseké még akkor is, ha a fiatalkor felső határát felfelé toljuk, az időskor alsó határát pedig szintén megemeljük. Magyarországon az öregedési fordulópontok 1990 és 2025 között jelentkeznek, mikor az idősek száma meghaladja a fiatalokét (az öregedési index meghaladja az 1-et). A demográfiai öregedést fokozza az alacsony gyermekszám, a növekvő élettartam, az elvándorlás, míg a népesség átlagos életkorára csökkentő hatást gyakorol a magasabb gyermekszám, a stagnáló vagy romló halandóság és a bevándorlás [KSH, 2004].

Az 1960-as években magas születési ráta volt megfigyelhető, azonban az 1980-as évektől a mai napig jellemző folyamat valamennyi európai országot tekintve, hogy a halálozások száma meghaladja a születésekét. A népesség öregedése az 1990-es évektöl figyelhető meg Európában, mely a születések alacsony számával, a halálozási arány csökkenésével és a Babyboom ${ }^{1}$ generáció nyugdíjas korhoz való közeledésével magyarázható [EUROPEAN COMISSION, Directorate General for Agriculture, 2006]. A korfa jelzi az adott népesség korstruktúrájának típusát, mely Magyarország esetében hagyma vagy urna alakot vesz fel, amit azt jelenti, hogy öreg korösszetételü, fogyó típusú népesség jellemző (1. ábra). A korfa alja folyamatosan keskenyedik, mely azt jelzi, hogy egyre kevesebb gyermek születik. A teteje szélesedik, mert nő a születéskori várható élettartam, az idősek száma egyre gyarapszik.

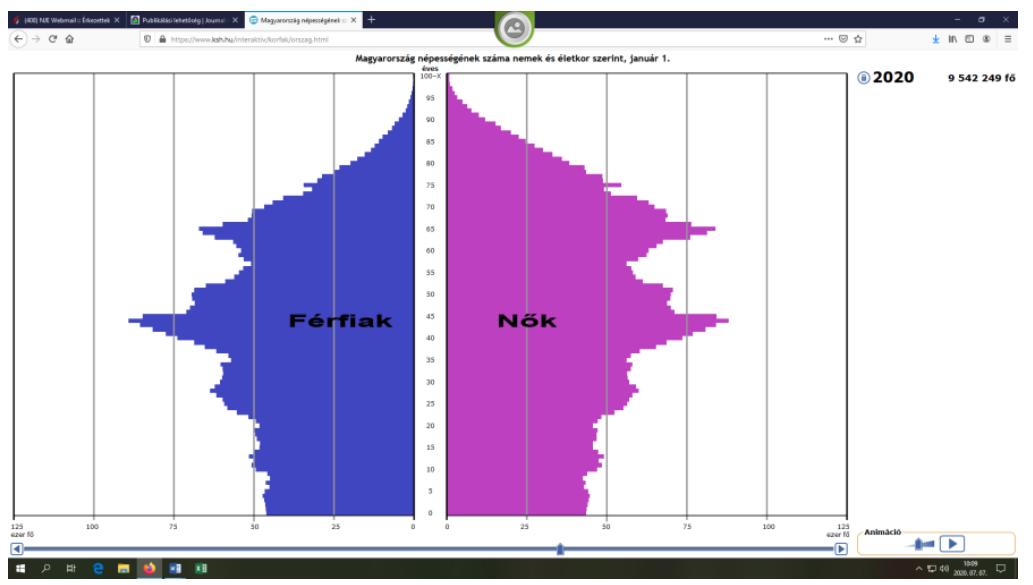

1. ábra: Magyarország korfájának alakulása

Figure 1. Population pyramid of Hungary

Forrás: KSH Interaktív korfa 2020. január 1-jén

${ }^{1}$ Baby-boom generáció: A világháború után született nemzedék, a mai 50-70 évesek korcsoportja. 
A KSH (2016) Magyarország 2015 kiadványában is olvashatjuk, hogy a fejlett európai országokhoz hasonlóan Magyarország számára is az egyik legnagyobb demográfiai kihívás a társadalom öregedése. Magyarországon 1990 óta a 15 éven aluli gyermekek aránya 20,5\%-ról 14,5\%-ra mérséklődött, miközben a 65 éveseké és annál idősebbeké 13,2\%-ról 18,3\%-ra gyarapodott. Az elöregedő társadalom a mezőgazdaságban dolgozó, mezőgazdasági tevékenységet folytató gazdálkodók elöregedését is maga után vonja, így részben ez is magyarázatot ad az agrártársadalom öregedésére, a generációváltás problémájára, nehézségeire.

Ember és Mihálovits (2007) munkájában kiemeli, hogy rohamosan öregszik a magyarországi agrártársadalom, a lassan nyugdíjba vonuló gazdák, tsz- és cégvezetök helyét csak ritkán veszik át fiatalok, számukra nem jelent perspektívát a mezőgazdaság. Az elöregedő korstruktúrából következik, hogy meglehetősen jelentős azon gazdák száma, akik az elkövetkezendő 5-10 évben felhagynak a mezőgazdasági tevékenységgel vagy átadják gazdaságukat a fiatalabbaknak [SZÉKELY, 2009]. A fiatalabb munkavállalókat elsősorban az átlag alatti munkabérek, a kedvezőtlen munkakörülmények, a mezőgazdasági tevékenység alacsony társadalmi és erkölcsi presztízse tereli más ágazatok felé [MÉSZÁROS-SZABÓ, 2014].

\section{Fiatal gazda kérdés az EU-ban és Magyarországon}

A mezőgazdaságnak nem csak egyetlen célja az élelmiszertermelés, hanem fontos szerepet játszik a vidéken élők és közösségeik életében, a vidék és a természeti erőforrások fenntartásában. A termelök tartják életben a vidéket, a falusi életformát. Gazdálkodók nélkül a vidék települései gyökeresen megváltoznának, mely az egész társadalomra károsan hatna. A gazdálkodás és az élelmiszer-előállítás a társadalom és a gazdaság számára nélkülözhetetlen [EURÓPAI BIZOTTSÁG, 2017]. Az Európai Unió tagországairól elmondható, hogy a mezőgazdaságban dolgozók aránya folyamatosan csökken, mely a fiatal gazdálkodók alacsony részarányával párosul. Az EUROSTAT 2013-ban végzett felmérése szerint az EU-ban a 65 éves vagy annál idősebb gazdák 31\%-ot képviseltek az összes gazdálkodóból. (2. ábra)

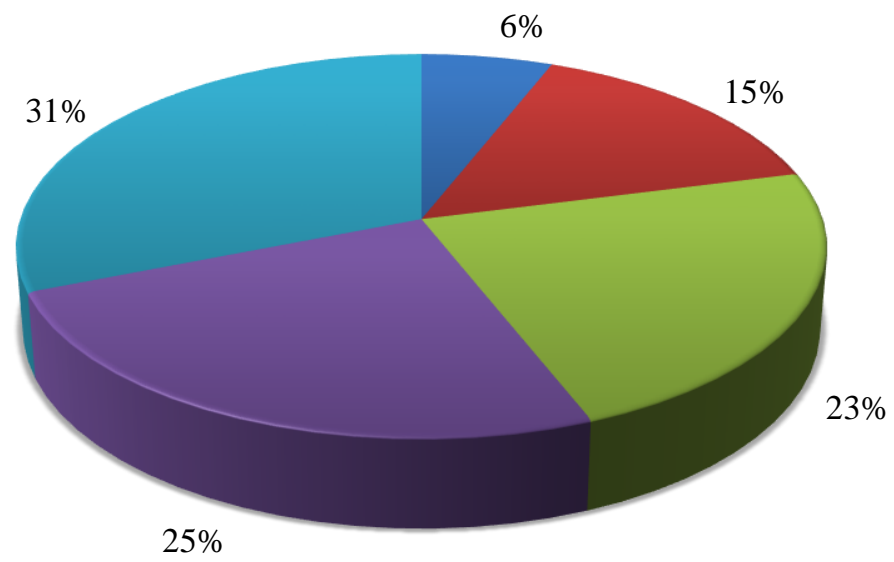

$\square 35$ év alatt

๑35-44 év

$\square 45-54$ év

๑55-64 év

$\square 65$ év felett

2. ábra: Gazdálkodók kormegoszlása az EU-ban, 2013

Figure 2. Farmers' agestructure in the EU (2013)

Forrás: EUROSTAT, 2015. 
Magyarország az EU átlagához képest hasonló képet mutat a gazdálkodók korszerkezetét illetően (1. táblázat). A 65 év vagy a fölötti gazdálkodók aránya 30,3\%, míg a 35 év alattiak aránya $6,1 \%$ volt 2013-ban az EUROSTAT (2015) adatai alapján.

1. táblázat: A gazdálkodók kormegoszlása az Európai Unió tagállamaiban, 2013 (\%) Table 1. Farmers' agestructure (\%) in the EU Member States (2013)

\begin{tabular}{|c|c|c|c|c|c|c|c|c|c|c|c|}
\hline ország & $<35$ év & $\begin{array}{c}35- \\
44 \\
\end{array}$ & $\begin{array}{c}45- \\
54 \\
\end{array}$ & $\begin{array}{c}55- \\
64 \\
\end{array}$ & $65 e ́ v<$ & ország & $<35 e ́ v$ & $35-44$ & $45-54$ & $55-64$ & $65 e ́ v<$ \\
\hline Ausztria & 10,9 & 24,4 & 36,5 & 19,6 & 8,6 & Lettország & 5 & 14,5 & 26,2 & 24,1 & 30 \\
\hline Belgium & 4 & 15,2 & 32,9 & 26,8 & 21,2 & Litvánia & 5,6 & 13,9 & 25,6 & 20,9 & 34 \\
\hline Bulgária & 6,4 & 13,2 & 18,5 & 25,2 & 36,7 & Luxemburg & 8,7 & 17,3 & 32,2 & 27,4 & 14,4 \\
\hline Horvátország & 4 & 9,9 & 21,8 & 29,1 & 33,3 & Málta & 3,8 & 12,9 & 24,8 & 33,4 & 25,1 \\
\hline Ciprus & 1,7 & 6,9 & 21,5 & 30,1 & 40 & Hollandia & 3,1 & 16,3 & 32,7 & 26,9 & 21 \\
\hline Csehország & 4,6 & 14,8 & 23,8 & 33,9 & 23 & Norvégia & 8 & 21,2 & 31,3 & 26,5 & 13 \\
\hline Dánia & 2,5 & 14,7 & 31,2 & 27,6 & 24 & Lengyelország & 12,1 & 23,7 & 30,2 & 24,3 & 9,6 \\
\hline Észtország & 7,5 & 16,8 & 23,4 & 21,8 & 30,4 & Portugália & 2,5 & 7,2 & 16,6 & 23,6 & 50,1 \\
\hline Finnország & 8,5 & 22 & 30,1 & 29,2 & 10,2 & Románia & 4,7 & 13,9 & 16,9 & 23,5 & 41 \\
\hline Franciaország & 8,8 & 19,1 & 32,7 & 27 & 12,4 & Szlovákia & 8,1 & 15,4 & 24,9 & 30 & 21,6 \\
\hline Németország & 6,8 & 19,7 & 37,2 & 29,8 & 6,5 & Szlovénia & 4,8 & 14,4 & 2416,4 & 29,1 & 25,3 \\
\hline Görögország & 5,2 & 14,7 & 23,9 & 24,9 & 31,3 & Spanyolország & 3,7 & 12,7 & 25 & 25,2 & 33,3 \\
\hline Magvarország & 6,1 & 14,9 & 19,4 & 29,2 & $\mathbf{3 0 , 3}$ & Svédország & 4,4 & 12,8 & 24,8 & 28 & 30 \\
\hline Írország & 5,7 & 15,2 & 23,7 & 26,1 & 29,4 & $\begin{array}{l}\text { Egyesült } \\
\text { Királyság }\end{array}$ & 3,9 & 11 & 26,6 & 27,9 & 30,6 \\
\hline Olaszország & 4,5 & 10,8 & 21,6 & 23,3 & 39,7 & $\boldsymbol{E} \boldsymbol{U}$ & 6 & 15,2 & 22,9 & 24,7 & 31,1 \\
\hline
\end{tabular}

Forrás: EUROSTAT, 2015.

Lengyelországban, ahol a fiatal gazdák aránya is kedvezőbb képet mutat, a munkavállalók közel 16\%-a foglalkozik még mindig mezőgazdasággal, de ez az arány évente itt is folyamatosan csökken. A vidéki területeken élők száma ezzel ellentétben növekszik (jelenleg 38,8\%), a falu vonzóvá válik az infrastruktúra még fennálló, meglévő hiányosságai ellenére is [KIEŁBASA, 2016]. A fiatalok a szélesebb kínálatú továbbtanulási lehetőségek miatt gyakran mennek nagyobb városokba, ahol a tanulmányaik befejezése után ott is maradnak, ott kezdenek el dolgozni, így a vidéki térségek lakosságszáma folyamatosan csökken és öregszik.

A 3. és a 4. ábra a gazdák korstruktúrájának megoszlását mutatja a kis és a nagy gazdaságokban az EU 28 országára vetítve. 


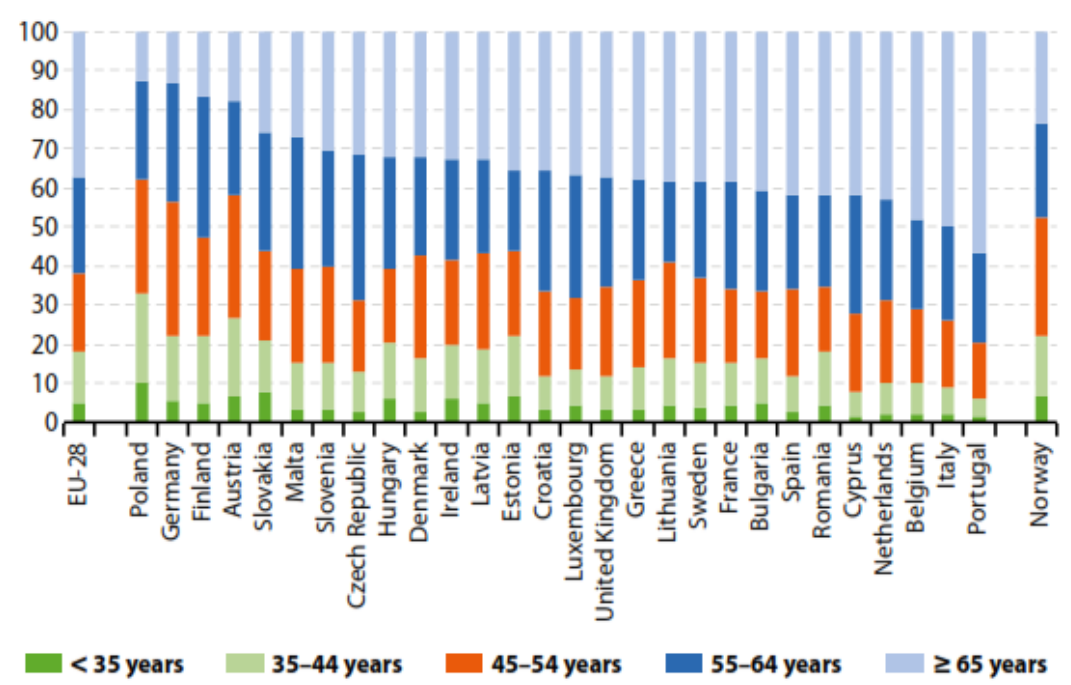

3. ábra: A gazdálkodók kormegoszlása a nagyon kicsi és kisgazdaságokban az EU tagállamaiban, $2013(\%)$

Figure 3. Farmers'agestructure (\%) in the very small and small farms in the EU Member States (2013)

Forrás: EUROSTAT, 2016/b

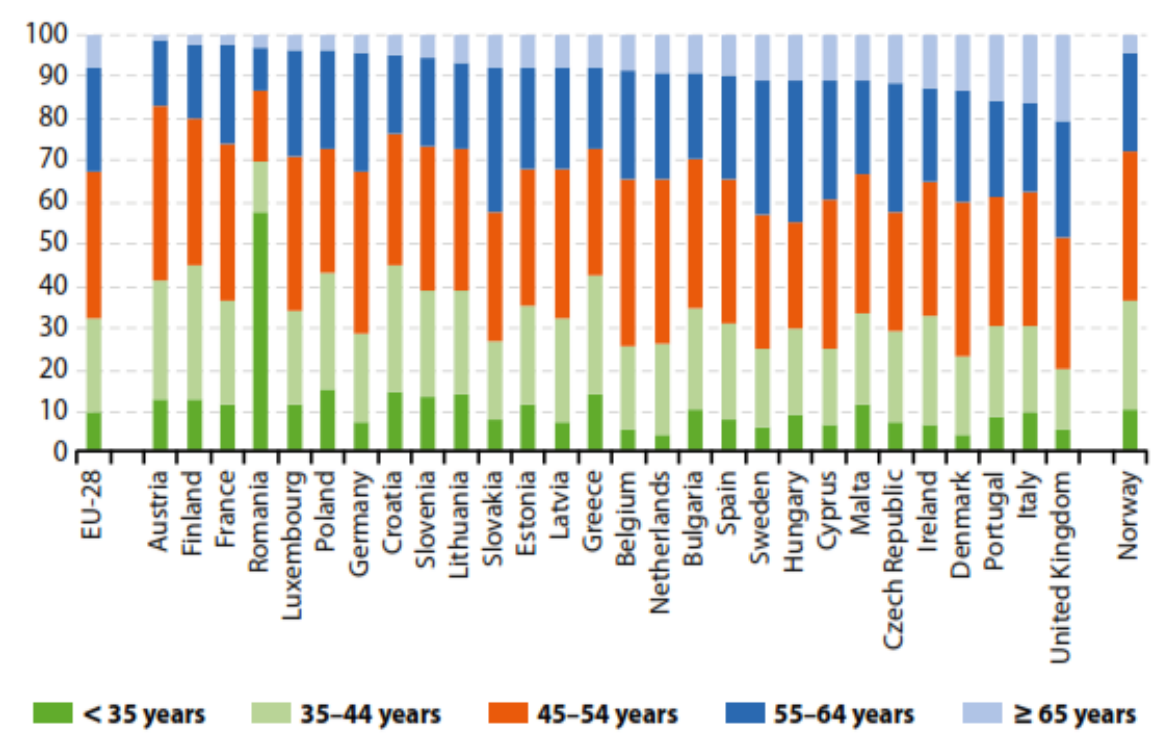

4. ábra: A gazdálkodók kormegoszlása a nagy gazdaságokban az EU tagállamaiban, $2013(\%)$

Figure 4. Farmers' agestructure (\%) in the large farms in the EU Member States (2013) Forrás: EUROSTAT, 2016/b

Az EU (és benne Magyarország) agrárgazdaságának egyik legnagyobb gondja a kedvezőtlen termelői korstruktúra, a fiatal gazdálkodók alacsony részaránya. (2. táblázat)

2016-ban az egyéni gazdálkodók 31\%-a volt 65 év feletti és csak 6\%-a 35 év alatti [KSH, 2016]. Az EU 28 tagállamában 10,7 millió gazda életkorát tekintve 31,3\%-uk volt 65 év feletti, mely körülbelül 3,3 millió gazdálkodót jelent. A déli országokban ez az arány $40 \%$ körül alakul. A generációváltás problémáját tükrözi, hogy a 35 év alatti gazdák aránya 5,8\% [EUROPEAN COMISSION, 2012]. 
2. táblázat: A gazdálkodók száma az egyéni gazdaságokban, korcsoportok szerint, 2010. Table 2. Number of farmers in the individual farms by age group (2010)

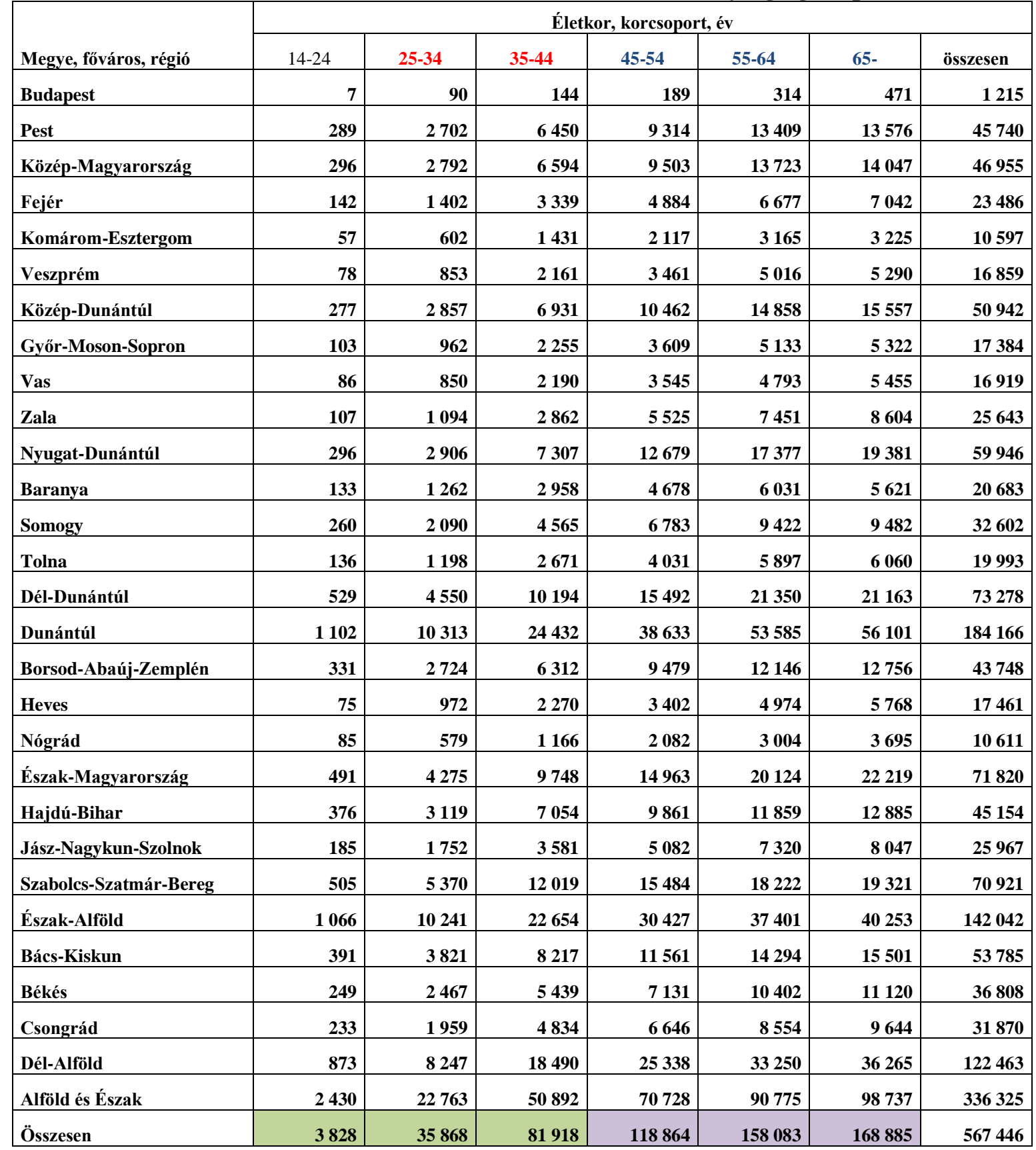

Forrás: KSH (2010)

Az AGRYA és a KSH 2013-ben végzett közös felmérése alapján elmondható, hogy a 2000es ÁMÖ óta eltelt időszakban a lakosság egyre kisebb hányada foglalkozott mezőgazdasági tevékenységgel. 2010-ben az egyéni gazdaságokban alig több mint 76 ezer 40 évesnél fiatalabb gazdálkodó folytatott mezőgazdasági termelést, feleannyi, mint tíz évvel korábban. A fiatal gazdák száma Nógrád, Győr-Moson-Sopron és Heves megyében fogyott leginkább, a legkevésbé pedig Szabolcs-Szatmár-Bereg megyében.

2010-ben az egyéni gazdálkodók korösszetétele kedvezőtlenebb képet mutatott, mint tíz évvel korábban, az egyéni gazdaságokat a kívánt generációváltás helyett az elöregedés jellemezte. A negyven évesnél fiatalabbak aránya 2010-ben csak kevéssel haladta meg a 13\%ot. 
2010-ben a fiatalok körében 3\% körül alakult a felsőfokú, 9\% körül a középfokú szakmai képzettséggel rendelkezők hányada. A legiskolázottabb fiatal egyéni gazdálkodók GyőrMoson-Sopron, a legkevésbé iskolázottak Borsod-Abaúj-Zemplén megyében tevékenykedtek.

A fiatal gazdálkodók arányát minden megyében csökkenés jellemezte 2010-ben, 2000-hez képest. (5. ábra)

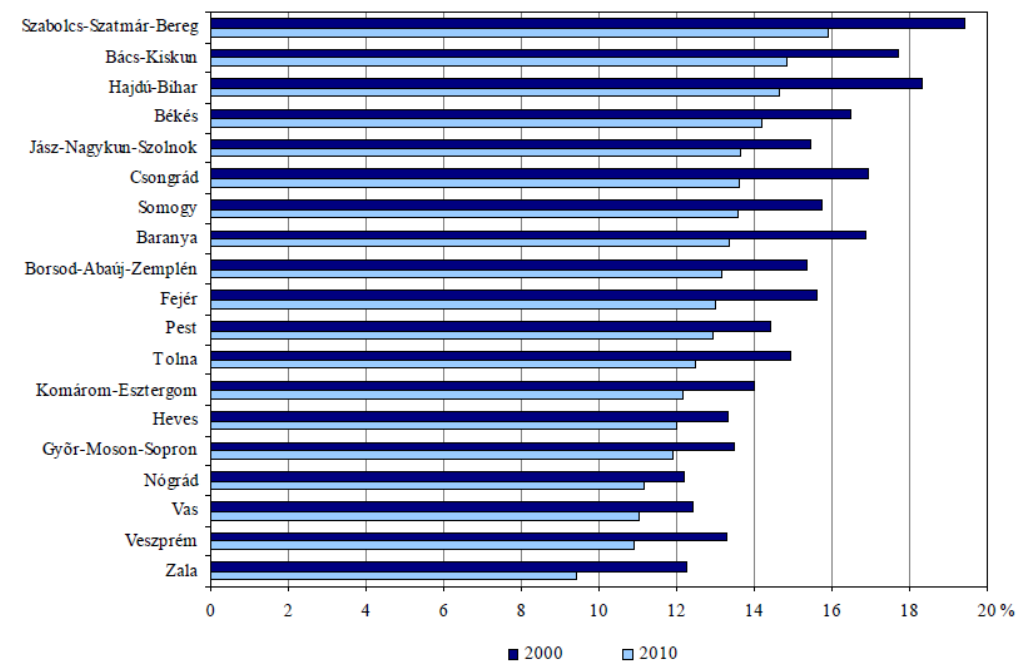

\section{5. ábra: A fiatal egyéni gazdálkodók aránya megyénként 2000-ben és 2010-ben}

Figure 5. Proportion of individual young farmers by counties $(2000,2010)$

Forrás: Laczka-Weisz, 2013. 11. p.

\section{A mezögazdaságban foglalkoztatottak szakképzettsége}

A földet érintő népességnövekedés következtében az elkövetkező 40 évben $60 \%$-kal kell növelni a mezőgazdaság termelését úgy, hogy a termőföld-területek mintegy negyede már ma is folyamatosan veszít termőképességéből, mindemellett a biodiverzitás csökkenése és a globális klímaváltozás kihívásai is egyre növekvő mértékben sújtják az ágazatot [POPP et al., 2014]. Az élelmezési és takarmányozási célú növénytermesztésre használható termőföldek átállítása energianövények termelésére visszhangott váltott ki nemcsak az energetika és az élelmezésügy, hanem az agrárközgazdaság-tudomány és az agrármenedzsment területén is [POPP et al., 2016]. A mezőgazdasági termelés növeléséhez azonban nemcsak a termelés technológiai vagy biológiai fejlesztésével lehet hozzájárulni, hanem azoktatás fejlesztése is kiemelt fontosságú terület. A mezőgazdasági szakképzés az agrárium fejlődésének egyik kiemelten fontos tényezője, hiszen feladata, hogy a tanulók és a hallgatók olyan korszerü elméleti és gyakorlati ismeretekkel rendelkezzenek, amelyek nemzetközi viszonylatba is versenyképesek [KSH, 2015]. Az ágazat magyarországi jelentőségét erősíti továbbá az a tény is, hogy az Európai Unió finanszírozásában megvalósuló fejlesztési tervek egyik kiemelt fókuszterülete az agrár-innováció [MATKÓ et al., 2015], amely célok a mezőgazdasági munkaerő fejlesztése nélkül nem elérhetőek. További célja, hogy továbbképzési lehetőségeket biztosítson az agrárszektorban dolgozók számára, az új technológiai módszerek, jogszabályi előírások, piaci információk megismerése érdekében. A fiatal gazdálkodók jövedelemszerzési lehetőségeit nemcsak a társadalomban lezajló demográfiai és foglalkoztatáspolitikai változások befolyásolják, hanem a szakképzettségük is meghatározó. A versenyképes és hatékony mezőgazdasághoz pedig elengedhetetlen a humánerőforrás megfelelő képzettsége [KSH, 2015]. 
Egy lengyelországi tanulmányban részt vevő gazdálkodók megerősítették, hogy az oktatás és a birtokolt tudás nagy hatással van a gazdaság fejlesztésére és hozzájárulnak a termelök innovatív hozzáállásának megteremtéséhez. Az empirikus tanulmányok azt mutatják, hogy a gazdák életkora és a képzettségi szint nagymértékben befolyásolja az innovációhoz való hozzáállásukat. A fiatal, jól képzett gazdák hajlandóak nagyobb kockázatot vállalni, érdeklődnek az innováció, az új dolgok iránt. Az innovációk megvalósítása nem csak a tudást igényli, hanem a pénzügyi forrást is. Az új technológiák egyre drágábbá válnak, ezért az agrárpolitikának biztosítania kell a gazdálkodók innovatív tevékenységének támogatását [KIEŁBASA, 2016].

A XXI. századi korszerü termelési technológiák, a támogatások pályázati anyagának összeállítása, az értékesítési piacok felkutatása és igényeik feltérképezése, a vállalkozást érintő uniós jogszabályok változásainak követése, olyan mindennapos kihívások az agrárvállalkozók számára, melyeknek naprakész szakértelem hiányában nem lehet megfelelni. Alvincz és Varga már 2000-ben felhívta a figyelmet arra, hogy a legmagasabb iskolai végzettség és a birtokméret között egyértelmü összefüggést találtak, miszerint a legnagyobb birtokmérettel a legmagasabb iskolai végzettségüek rendelkeznek. Ugyanakkor a szerzők felmérése szerint a veszteséges gazdaságok átlagot meghaladó aránya a felsőfokú végzettségüek körében fordul elö. A hitel felvétele és annak fajlagos összege is nagyobb a magasabb végzettségüeknél. A gazdaságméret növelésében az alapfokú végzettségüek a legkevésbé érdekeltek [ALVINCZ - VARGA, 2000].

2006-ban készült empirikus kutatás az agrárszektorban elhelyezkedni szándékozó fiatalokat vizsgálta [KOMLÓSI, 2008]. A kutatás egyértelmüvé tette, hogy a fiatalok azon csoportjának nagyobb az esélye a helytállásra, akik kellőképpen elkötelezettek szakmájuk iránt, megfelelő mértékben motiváltak, nyitottak, illetve kreatívak. A felmérés rávilágított arra is, hogy a mintába került mezőgazdasági szakiskolai, szakközépiskolai tanulók, valamint agrárfőiskolai/egyetemi hallgatók szakmájuk iránti elkötelezettségét, hozzáállását a fiatalok családból hozott társadalmi, gazdasági és kulturális tőkéje, azaz az egyént jellemző szocioökonómiaifaktorok erőteljesebben befolyásolják, mint az alapfokú oktatási intézmények.

Magyarországon az elmúlt másfél évtizedben javult a mezőgazdasági foglalkoztatottak iskolázottsága, de még mindig alul marad a többi nemzetgazdasági ághoz képest. A KSH 2005ben készült mikrocenzusa idején egyharmaduk semmilyen szakképesítéssel nem rendelkezett, legfeljebb az általános iskola 8 osztályát végezte el. Felsőfokú végzettsége pedig, csupán 9\%uknak volt.

A 2010. évi ÁMÖ adatai szerint a 9,2 ezer gazdasági szervezet irányítójának 73\%-a (6,7 ezer fö) rendelkezett valamilyen mezőgazdasági végzettséggel. 44\%-uk felsőfokú, $22 \%$-uk középfokú, 7\%-uk pedig alapfokú végzettség volt a birtokában. 21\%-uk gyakorlati tapasztalatokra, 6\%-uk pedig szakmai képesítésre támaszkodott a gazdálkodás során. Az egyéni gazdaságokra jellemzőbb az alacsonyabb iskolázottsági szint. A gazdálkodók és a segítő családtagok jelentős része, $76 \%$-uk mezőgazdasági végzettség nélkül, gyakorlati tapasztalatokra támaszkodott vagy e nélkül (14\%) gazdálkodott [KSH, 2015].

A KSH 2011. évi népszámlálás adatai alapján a teljes népesség 2,0\%-a, több mint 200 ezer ember rendelkezett valamilyen mezőgazdasági végzettséggel. Területi eloszlásukat tekintve közel azonos arányban, a fövárosban és Pest megyében éltek a legtöbben, de jellemzően a hat alföldi (Bács-Kiskun, Békés, Csongrád, Hajdú-Bihar, Jász-Nagykun-Szolnok, SzabolcsSzatmár-Bereg), valamint Borsod-Abaúj-Zemplén és Győr-Moson-Sopron megyében is jelentős volt az agrárvégzettségü népesség aránya.

A mezőgazdaságot, mint szakmát a 30-34 és a 60-64 év közöttiek választották a legtöbben. A mezőgazdasági végzettséggel rendelkező gazdálkodók és segítő családtagjaik $20 \%$-a felső-, 44\%-a közép-, és 36\%-a alapfokú képesítéssel rendelkezett. A népességszámra vetítve a mezőgazdasági végzettségüek száma kiemelkedik Bács-Kiskun, Békés és Somogy megyékben, míg Budapesten él a legkevesebb mezőgazdasági végzettségü. A korcsoportokat vizsgálva a 
mezőgazdasági végzettségüek aránya a 30-34 és a 60-64 év közöttiek közt volt a legmagasabb. A szakképzett munkaerőre szükség van a mezőgazdasági termelés tekintetében kiemelt területeken. A gazdálkodás szempontjából kedvező természeti adottságok, a gazdasági fejlettség, a munkaerő-piaci és kereseti lehetőségek befolyásolják a mezőgazdasági szakma iránt érdeklődő pályaválasztókat. A gazdálkodók képzése és továbbképzése kiemelten fontos feladat, mivel képzettségük szintje még ma is igen alacsonynak mondható [KSH, 2015].

Az egyéni gazdaságokban a gazdálkodók és segítő családtagok mezőgazdasági iskolázottsági szintje jóval alacsonyabb, mint a gazdasági szervezetek irányítóié. Esetükben átlagosan 10\% körül alakult a szakmai képesítéssel rendelkezők aránya, amely összességében mintegy 110 ezer főt jelentett. A gazdálkodók és segítő családtagok jelentős többsége mezőgazdasági képzettség nélkül, gyakorlati tapasztalat alapján (76\%) vagy annak hiányában $(14 \%)$ gazdálkodott. Az egyéni gazdaságokban a mezőgazdasági végzettségüek 20\%-a felsőfokú, 44\%-a középfokú, 36\%-a pedig alapfokú szakmai képesítéssel rendelkezett [KSH, 2015]. A fiatal gazdaságvezetőkről elmondható, hogy az átlagosnál többen rendelkeznek közép- és felsőfokú szakirányú végzettséggel [AGRYA, 2018].

2002 és 2012 között a KSH adatai alapján csökkent a közép- és felsőfokú agrárképzések iránti érdeklődés, ezzel ellentétben az iskolarendszeren kívüli mezőgazdasági képzések iránt nőtt a kereslet [KSH, 2015]. A fiatal pályakezdők körében egyre kevésbé népszerüek a mezőgazdasági képzések, mely részben azzal is magyarázható, hogy már nem olyan „divatos” a fiatalok körében. Ez azonban nem azt jelenti, hogy csökken a mezőgazdaság iránti kötődésük. (DAJNOKI - KUN, 2016) Kovách (2012) kutatása azt mutatta, hogy a magyar felnőtt lakosság 61,5\%-a volt agrárérintett, melynek 51,6\%-a közvetlenül és 10\%-a szülei révén, közvetetten füződött a mezőgazdasághoz. Az OECD (2017) felmérése alapján Magyarországon az összes diplomás mintegy 3\%-a szerez felsőfokú agrárvégzettséget, amely meghaladja az OECD és az EU-22 2\%-os átlagát. Lakner (2012) munkájában rávilágít arra, hogy miközben egyes írásokban azt olvashatjuk, hogy jelentős túlképzés tapasztalható Magyarországonaz agárszakokon, addig a rohamosan csökkenő beiskolázási keretszámok a felsőoktatásban néhány év múlva agrárszakember hiányt vetítenek elöre.

A fiatalabb gazdálkodók között kedvezöbb a végzettség szerinti összetétel. A 35 év alattiakkörében $6,4 \%$ rendelkezik felsőfokú végzettséggel, a nyugdíj előtt állók esetében ez mindössze 3,2\%. Viszont a legfiatalabb korosztály esetében is fontos megjegyezni, hogy 69\%uk nem rendelkezik semmiféle mezőgazdasági végzettséggel [KSH, 2016]. A jövőben nagy kihívást jelent rávenni a fiatalokat arra, hogy mezőgazdasággal foglalkozzanak és hajlandóak legyenek átvenni a családi gazdaságokat. A jövő mezőgazdaságának kiemlet célja lesz az élethosszig tartó tanulás, hiszen az innovációk és a technológiai fejlődés ezt megköveteli. Fontos a jól képzett, minőségi tudással rendelkező szakemberek megléte, hiszen érdemi munkát és versenyképes gazdálkodást csak ők képesek folytatni.

Szűcs és Zörög (2013) felmérésükben megállapítják, hogy vezetői szinten az agrárdiplomások nagyobb arányban jelennek meg, mint a többi képzési területen. Ennek megfelelően a többi területtel összevetve gyorsabb az elörelépés lehetősége. Ezt az eredményt azért tartják kiemleten fontosnak, mert Magda és társai (2008) úgy látják, hogy az agrárképzés népszerüségvesztésen ment keresztül az elmúlt években többek között a kedvezőtlen megbecsülés, az alacsony fizetés miatt. A pályaválasztók körében minőségromlás figyelhető meg az oktatás tömegesedése, a visszaeső színvonalú előképzettség miatt. A fiatalok napjainkban kevésbé érett személyiségek, mint 10-15 évvel ezelött. Ennek oka a következetes, kitartó munka hiánya lehet. A tanulmányban megerősítésre került, hogy a kevéssé motivált hallgatók oktatásához új módszerek alkalmazása, a gyakorlati képzés előtérbe helyezése és a megfelelő motivációs rendszer kialakítása szükséges. Az ágazatban tapasztalható gyorsabb elörelépés lehetősége tehát vonzó lehet a pályaválasztók körében, azonban összességében kutatásuk arra világít rá, hogy az agrárképzési területen végzett hallgatók - kezdeti 
hipotézisükkel ellentétben - az átlagosnál lassabban tudnak elhelyezkedni a záróvizsga után. Sajnálatos módon az agrárvégzettségüek negyedénél állapítható meg, hogy semmiféle kapcsolat nincs a munkájuk és a végzettségük között. A kutatásuk eredményeként megállapították, hogy az agrárdiplomásoknak gyorsabb karrierépítésre nyílik lehetősége az egyéb képzési területen végzett munkavállalókkal szemben. Véleményük szerint ez fontos lehet a beiskolázási stratégia kialakításánál. A felmérés további fontos eredményének tartják, hogy a kérdőívet kitöltő diplomás alkalmazottak úgy nyilatkoztak, hogy a diplomájukat kiállító felsőoktatási intézmény nem segíti eléggé öket az első munkahelyükhez való hozzájutásban. Ennek alapján a felsőoktatási intézményeknek nagyobb hangsúlyt kellene fektetni arra, hogy hallgatóikat támogassák első munkahelyük felkutatásában. Ennek egyik lehetőségét abban látják, hogy egy olyan portált alakítsanak ki, amely a munkaerö-piaci szereplők számára elérhető adatbázisban nyilván tartja a végzés előtt álló, illetve végzett hallgatóikat. A munkaadók üzemi gyakorlatra, végleges foglalkoztatás céljából kereshetnének a kínált munkakör betöltésére alkalmas képességekkel, készségekkel rendelkező hallgatót [SZÜCSZÖRÖG, 2013], amely véleményünk szerint a kecskeméti Kertészeti és Vidékfejlesztési Karon kiemelten müködik, ahol a feléves szakmai gyakorlatot letöltő hallgatók része a gyakorlati helyen el tud helyezkedni. Ezen kívül a másik oldalról a hallgatóknak is lehetővé válna a felsőoktatási intézménnyel együttmüködő vállalatok közül megkeresni azt, amelyik fogadni tudja a féléves üzemi gyakorlatra [SZÜCS-ZÖRÖG, 2013].

\section{Anyag és módszer}

Szekunder kutatás keretében, a felvi.hu [FELVI, 2020] adatai alapján 2001-től vizsgáljuk az agrárképzésre jelentkezők létszámának alakulását. 2008. évtől kezdődően államilag támogatott, költségtérítéses és a pótfelvételi eljárás keretében külön kerülnek feltüntetésre a felvételi létszámok mind a jelentkezők, mind pedig a felvételt nyertek tekintetében, azonban a könnyebb átláthatóság keretében ezek az adatok összevontan szerepelnek az adott években. Az Eurostat adatainak segítségével, pedig az EU 2016-os adatára támaszkodva megnéztük, hogy milyen képzési területek a legnépszerübbek a továbbtanulni szándékozó fiatalok szerint.

\section{Eredmények}

\section{Az agrár-felsőoktatásban tanulók létszámadatainak alakulása}

Az agrár-felsőoktatásról elmondható, hogy Magyarországon évtizedekre visszavezethető hagyományai vannak. A'60-as években jelentősen megnőtt az agrár-felsőoktatásban részt vevő hallgatók létszáma. A rendszerváltás és a mezőgazdaság jövedelemtermelő képességének csökkenése következtében azonban az agrár-felsőoktatás fokozatosan veszített vonzerejéből [HERNECZKY, 2011] és a népszerüségének csökkenése a mai napig megfigyelhetö. Az agrárképzés számára nemcsak a mennyiségi változások voltak kedvezőtlenek, hanem az oktatás minősége sem felelt már meg az új követelményeknek. A nagy szakmai múlttal rendelkező intézmények fennmaradása múlhat azon, hogy képesek-e az innovációra [HERNECZKY, 2011].

Ha a nemzetközi adatokat vizsgáljuk, akkor az Eurostadt adatai alapján elmondható, hogy EU-28 (Norvégia nélkül) területén az összes felsőoktatási hallgató majdnem egyharmada $(32,0 \%)$ tanult társadalomtudományokat, újságírást, kommunikációt, gazdaságot, közigazgatást 
vagy jogot 2016-ban. A második legnépszerübb képzési terület a müszaki, ipari és építőipari képzések voltak, amelyben az összes felsőoktatási hallgató 15,7\%-a tanult. A harmadik legnépszerübb képzési terület az egészségügyet és a szociális területet foglalta magában, amelyben az összes felsőoktatási hallgató 13,4\%-a vett részt. A mezőgazdasági, erdőgazdálkodási, halgazdálkodási és állatorvosi képzések a legnépszerütlenebbek a jelentkezők körében, mivel az összes továbbtanulni szándékozó 1,9\%-a választotta ezt a képzési területet (a nemek közötti megoszlás tekintetében, azonban ezen a képzési területen nem látható lényeges különbség) (3. táblázat).

\section{3. táblázat: A felsőoktatási hallgatók megoszlása képzési terület és nemek szerint, EU-28, $2016 \%$}

Table 3. Distribution of tertiary education students by field and sex, EU-28, $2016 \%$

\begin{tabular}{|c|c|c|c|}
\hline tudományág & férfi \% & nő\% & $\begin{array}{l}\text { összesen } \\
\text { képzési } \\
\text { területenként } \\
\%\end{array}$ \\
\hline $\begin{array}{l}\text { társadalomtudományok, újságírás és } \\
\text { kommunikáció; gazdaság, közigazgatás és jog }\end{array}$ & 13,6 & 18,4 & 32,0 \\
\hline müszaki, ipari és épitőipari képzések & 11,6 & 4,1 & 15,7 \\
\hline egészségügy, szociális gondozás & 3,8 & 9,5 & 13,4 \\
\hline müvészetek & 4,4 & 7,9 & 12,2 \\
\hline $\begin{array}{c}\text { információs és kommunikációs technológiák, } \\
\text { a természettudományok, a matematika és } \\
\text { statisztika }\end{array}$ & 7,5 & 4,8 & 12,3 \\
\hline oktatás & 1,6 & 5,8 & 7,4 \\
\hline szolgáltatások & 1,9 & 1,7 & 3,5 \\
\hline $\begin{array}{c}\text { mezögazdaság, erdögazdálkodás, halgazdálkodás } \\
\text { és állatorvosi tudományok }\end{array}$ & 0,9 & 0,9 & 1,9 \\
\hline ismeretlen adat & 0,7 & 0,9 & 1,6 \\
\hline
\end{tabular}

Forrás: Eurostat (2016) adatai alapján saját szerkesztés

A 4. táblázat az évenkénti jelentkezők és felvettek létszámát és \%-os megoszlásukat mutatja. Ha az agrárjelentkezők létszámát az összes jelentkezőhöz viszonyítjuk, akkor látható, hogy egyértelmüen ez alapján nem tudjuk kijelentkeni, hogy folyamatosan csökken az érdeklödés az agrárképzési szakok iránt. A legalacsonyabb jelentkezési létszám 2005-ben volt (5,68\%), a legmagasabb pedig az 2000-es évek elején (10,4\%), az összes jelentkezőhöz képest. Ha az agrárszakokra felvettek látszámát vizsgáljuk az összes felvett hallgatóhoz képest, akkor a legkevesebb agrárszakra jelentkezett hallgatót 2009-ben vették fel (3,96\%), a legtöbbet pedig 2002-ben (8,39\%). Az agrárszakokra jelentkezők és felvettek létszámának rapszódikusságát a képzési paletta változtatása, illetve a duális képzés bevezetése is befolyásolhatta. 
4. táblázat: A jelentkezők, illetve a felvettek száma és százalékos megoszlásuk (fő és \%) Table 4. Number and percentage distribution of applicants and admissions

\begin{tabular}{|c|c|c|c|c|c|c|c|c|}
\hline \multirow[b]{2}{*}{$\dot{E} v$} & \multirow{2}{*}{$\begin{array}{c}\text { Jelentkezők } \\
\text { Összesen } \\
\end{array}$} & \multirow{2}{*}{$\begin{array}{c}\text { Felvettek } \\
\text { Összesen }\end{array}$} & \multirow{2}{*}{$\begin{array}{c}\text { felvett } \\
\text { ek/jele } \\
\text { ntkezö } \\
k\end{array}$} & \multicolumn{2}{|c|}{$\begin{array}{c}\text { agrárszakokr } \\
\text { a jelentkezők } \\
\text { száma } \\
\end{array}$} & \multirow[b]{2}{*}{$\begin{array}{c}\text { agrárjelentkezök/ } \\
\text { jelentkezök }\end{array}$} & \multicolumn{2}{|c|}{ agrárszakokra felvettek száma } \\
\hline & & & & $\begin{array}{c}\ddot{O}_{s s z} \\
\text { esen }\end{array}$ & $\begin{array}{r}\text { Elsö } \\
\text { helyen }\end{array}$ & & Összesen & $\begin{array}{c}\text { agrárfelvettek/fel } \\
\text { vettek }\end{array}$ \\
\hline $\begin{array}{c}2019 \\
\text { P,Á,K }\end{array}$ & 126626 & 89609 & 70,77 & $\begin{array}{c}812 \\
1 \\
\end{array}$ & 5472 & 6,41 & 3917 & 4,37 \\
\hline $\begin{array}{c}2018 \\
\mathrm{P}, \mathrm{A}, \mathrm{K}\end{array}$ & 120937 & 84879 & 70,18 & $\begin{array}{c}827 \\
9\end{array}$ & 5696 & 6,85 & 4080 & 4,81 \\
\hline $\begin{array}{r}2017 \\
\mathrm{P}, \mathrm{A}, \mathrm{K} \\
\end{array}$ & 118766 & 82144 & 69,16 & $\begin{array}{c}841 \\
7 \\
\end{array}$ & 5662 & 7,09 & 4171 & 5,08 \\
\hline $\begin{array}{r}2016 \\
\mathrm{P}, \mathrm{A}, \mathrm{K}\end{array}$ & 124982 & 85019 & 68,02 & $\begin{array}{c}987 \\
2 \\
\end{array}$ & 6797 & 7,90 & 4998 & 5,88 \\
\hline $\begin{array}{c}2015 \\
\mathrm{P}, \hat{\mathrm{A}}, \mathrm{K}\end{array}$ & 119714 & 82897 & 69,25 & $\begin{array}{c}104 \\
68 \\
\end{array}$ & 6849 & 8,74 & 4900 & 5,91 \\
\hline $\begin{array}{c}2014 \\
\mathrm{P}, \mathrm{A}, \mathrm{K}\end{array}$ & 121446 & 86032 & 70,84 & $\begin{array}{c}110 \\
01 \\
\end{array}$ & 7294 & 9,06 & 5355 & 6,22 \\
\hline $\begin{array}{r}2013 \\
\text { P,Á,K }\end{array}$ & 109271 & 83354 & 76,28 & $\begin{array}{c}979 \\
1\end{array}$ & 6316 & 8,96 & 5320 & 6,38 \\
\hline $\begin{array}{c}2012 \\
\text { P,Á,K }\end{array}$ & 126574 & 92475 & 73,06 & $\begin{array}{c}960 \\
4 \\
\end{array}$ & 5928 & 7,59 & 4194 & 4,54 \\
\hline $\begin{array}{c}2011 \\
\mathrm{P}, \hat{\mathrm{A}}, \mathrm{K}\end{array}$ & 161731 & 115841 & 71,63 & $\begin{array}{c}112 \\
01 \\
\end{array}$ & 6981 & 6,93 & 5020 & 4,33 \\
\hline $\begin{array}{c}2010 \\
\mathrm{P}, \hat{\mathrm{A}}, \mathrm{K}\end{array}$ & 160033 & 114106 & 71,30 & $\begin{array}{c}114 \\
45\end{array}$ & 7187 & 7,15 & 4804 & 4,21 \\
\hline $\begin{array}{r}2009 \\
\text { P,Á,K }\end{array}$ & 143906 & 109336 & 75,98 & $\begin{array}{c}966 \\
3 \\
\end{array}$ & 5923 & 6,71 & 4325 & 3,96 \\
\hline $\begin{array}{c}2008 \mathrm{P}, \\
\mathrm{A}, \mathrm{K}\end{array}$ & 113896 & 96330 & 84,58 & $\begin{array}{c}748 \\
2 \\
\end{array}$ & 4783 & 6,57 & 4034 & 4,19 \\
\hline $\begin{array}{c}2007 / \\
\text { Á }\end{array}$ & 108928 & 81637 & 74,95 & $\begin{array}{c}826 \\
7 \\
\end{array}$ & 4758 & 7,59 & 3642 & 4,46 \\
\hline $\begin{array}{c}2006 / \\
\text { Á }\end{array}$ & 132771 & 94142 & 70,91 & $\begin{array}{c}998 \\
5 \\
\end{array}$ & 6152 & 7,52 & 4774 & 5,07 \\
\hline $\begin{array}{c}2005 / \\
\text { Á }\end{array}$ & 150232 & 103364 & 68,80 & $\begin{array}{c}853 \\
0 \\
\end{array}$ & 5994 & 5,68 & 5507 & 5,33 \\
\hline $\begin{array}{c}2004 / \\
\text { Á }\end{array}$ & 167371 & 109851 & 65,63 & $\begin{array}{c}123 \\
57 \\
\end{array}$ & 8437 & 7,38 & 7092 & 6,46 \\
\hline $\begin{array}{c}2003 / \\
\text { Á }\end{array}$ & 160217 & 106376 & 66,39 & $\begin{array}{c}115 \\
68 \\
\end{array}$ & 8178 & 7,22 & 6957 & 6,54 \\
\hline $\begin{array}{c}2002 / \\
\text { Á }\end{array}$ & 164703 & 109470 & 66,47 & $\begin{array}{c}171 \\
24 \\
\end{array}$ & $\begin{array}{c}1117 \\
2 \\
\end{array}$ & 10,40 & 9183 & 8,39 \\
\hline $\begin{array}{c}2001 / \\
\text { Á }\end{array}$ & 148880 & 98031 & 65,85 & $\begin{array}{c}143 \\
97 \\
\end{array}$ & 9254 & 9,67 & 7522 & 7,67 \\
\hline
\end{tabular}

\section{jelmagyarázat:}

K: februárban induló képzések felvételi eljárása

Á: szeptemberében induló képzések felvételi eljárása

P: szeptemberben induló képzések felvételi eljárása (pótfelvételi)

Forrás: felvi.hu adatai alapján saját szerkesztés 
Az 5. táblázatból látható, hogy a kétezres évek elején jelentkeztek legtöbben az agrárszakokra, azonban az utóbbi években a jelentkezések száma fokozatosan csökken. Az agrárképzést első helyen megjelölők száma nagyjából 60 és $70 \%$ között mozog az összes jelentkezéshez képest. A felvettek létszámában az utóbbi években enyhe csökkenés figyelhető meg az állam részéröl. 2020-ban várhatóan további csökkenés várható az agrárterület jelentkezőit illetően, mivel az előzetes adatok alapján egyre kevesebben szándékoznak továbbtanulni felsőoktatási intézményben. A csökkenés azonban nem újkeleltü, hanem folyamatosan érzékelhető, mivel 2005-ben még a teljes magyar népesség 4,2 százaléka, 2016ban már csak 2,9 százaléka járt felsőfokú képzésre valamilyen felsőoktatási intézményben. A csökkenés mögött az irodalmi áttekintésben már ismetetett demográfiai okok is húzódnak, hiszen a társadalmon belül a 18-24 éves korosztály létszáma is egyre csökken. Meg kell jegyeznünk, hogy a vizsgált időintervallumon belül az agrárszakok kínálata többször is változott. 2006-tól például új szakként jelent meg a képzési palettában a gazdasági és vidékfejlesztési agrármérnök BSc és a környezetgazdálkodási agrármérnök BSc képzés. 2017től új szak a mezőgazdasági mérnöki BSc képzés és a korábbi gazdasági és vidékfejlesztési agrármérnök BSc szak neve vidékfejlesztési agrármérnöki BSc szakként szerepel tovább. 2017ben a képzési terület három legnépszerübb alapszakja a mezőgazdasági mérnöki, az élelmiszermérnöki, valamint a vidékfejlesztési agrármérnöki alapképzések voltak. E szakokon nappali munkarendủ képzésre rendre 550, 440 és 317 jelentkező volt első helyen. Az elsőre 360, a másodikra 405, a harmadikra pedig 274 jelentkezöt vettek fel nappali alapképzésre. 2019-es felvételi eljárás keretében elmondható, hogy a legtöbb agrár-felsőoktatási intézményében nőtt az érdeklődés a mezőgazdasági képzések iránt. Intézményünkben, a kecskeméti Kertészeti és Vidékfejlesztési Karra összesen 423-an jelentkeztek agrárterületre, közülük 123-an jelölték meg első helyen az intézményt. A bekerülési ponthatár szakonként eltérő volt, de minimum 282-287 pont kellett a sikeres felvételihez. A jelentkezők összlétszáma nem változott az előző évhez képest az intézményben, a felvettek száma kissé növekedett. További újítás volt az agrárszakokra történő duális képzés bevezetése is. Intézményünkben 2015 szeptembere óta van lehetőségük a hallgatóknak duális képzés keretében szakot választani, azoban tapasztalataink szerint a duális hallgatók jelentős száma hadja ott tanulmányai során a képzési helyet. Ez többek között a duális képzés rugalmatlanságával is magyarázható.

\section{5. táblázat: Az agrárképzési területre jelentkezők és felvettek száma és százalékos megoszlása (fó és \%)}

Table 5. Number and percentage distribution of applicants and admissions in the field of agricultural training (persons and \%)

\begin{tabular}{|c|c|c|c|c|c|}
\hline \multirow{2}{*}{ év } & \multicolumn{3}{|c|}{ jelentkezők } & \multicolumn{2}{c|}{ felvettek } \\
\cline { 2 - 6 } & összesen & $\begin{array}{c}\text { első } \\
\text { helyen }\end{array}$ & $\begin{array}{c}\text { az elsö } \\
\text { helyen } \\
\text { jelenktezök } \\
\text { /jelentkezök }\end{array}$ & összesen & fekvettek/jelentkezök \\
\hline $\begin{array}{c}2019 \\
\text { K,Á,P }\end{array}$ & 8121 & 5472 & 67,38 & 3917 & 48,23 \\
\hline $\begin{array}{c}2018 \\
\text { K,Á,P }\end{array}$ & 8279 & 5696 & 68,8 & 4080 & 49,28 \\
\hline $\begin{array}{c}2017 \\
\text { K,Á,P }\end{array}$ & 8417 & 5662 & 67,27 & 4171 & 49,55 \\
\hline
\end{tabular}




\begin{tabular}{|c|c|c|c|c|c|}
\hline $\begin{array}{c}2016 \\
\text { K,Á,P }\end{array}$ & 9872 & 6797 & 68,85 & 4998 & 50,63 \\
\hline $\begin{array}{c}2015 \\
\text { K,Á,P }\end{array}$ & 10468 & 6849 & 65,43 & 4900 & 46,81 \\
\hline $\begin{array}{c}2014 \\
\text { K,Á,P }\end{array}$ & 11001 & 7294 & 66,3 & 5355 & 48,68 \\
\hline $\begin{array}{c}2013 \\
\text { K,Á,P }\end{array}$ & 9791 & 6316 & 64,51 & 5320 & 54,34 \\
\hline $\begin{array}{c}2012 \\
\text { K,Á,P }\end{array}$ & 9604 & 5928 & 61,72 & 4194 & 43,67 \\
\hline $2011 \mathrm{~K}, \mathrm{~A}, \mathrm{P}$ & 11201 & 6981 & 62,32 & 5020 & 44,82 \\
\hline $\begin{array}{c}2010 \\
\text { K,Á,P }\end{array}$ & 11445 & 7187 & 62,8 & 4804 & 41,97 \\
\hline $\begin{array}{c}2009 \\
\text { K,Á,P }\end{array}$ & 9663 & 5923 & 61,3 & 4325 & 44,76 \\
\hline $\begin{array}{c}2008 \\
\text { K,Á,P }\end{array}$ & 7482 & 4783 & 63,93 & 4034 & 53,92 \\
\hline $2007 / \hat{A}$ & 8267 & 4758 & 57,55 & 3642 & 44,05 \\
\hline $2006 / \hat{A}$ & 9985 & 6152 & 61,61 & 4774 & 47,81 \\
\hline $2005 / \hat{A}$ & 8530 & 5994 & 70,27 & 5507 & 64,56 \\
\hline $2004 / \hat{A}$ & 12357 & 8437 & 68,28 & 7092 & 57,39 \\
\hline $2003 / \hat{A}$ & 11568 & 8178 & 70,7 & 6957 & 60,14 \\
\hline $2002 / \hat{A}$ & 17124 & 11172 & 65,24 & 9183 & 53,63 \\
\hline $2001 / \hat{A}$ & 14397 & 9254 & 64,28 & 7522 & 52,25 \\
\hline
\end{tabular}

jelmagyarázat:

K: februárban induló képzések felvételi eljárása

Á: szeptemberében induló képzések felvételi eljárása

P: szeptemberben induló képzések felvételi eljárása (pótfelvételi)

Forrás: felvi.hu adatai alapján saját szerkesztés

\section{Következtetések}

A demográfiai összetetételben bekövetkező változás részben maga után vonja az agrártársadalom elöregedését is, azonban a gazdák elöregedő korstruktúrája mellett kiemelt probléma a mezőgazdaságban dolgozók, gazdálkodók szakirányú iskolai végzettségének hiánya. A mezőgazdasági szövetkezetek megalakulása a rendszerváltás előtti időkben az agrárvégzettséggel rendelkező fiatalok számára megfelelő munkalehetőséget jelentettek, azonban ezek felszámolásával csökkent az elhelyezkedési lehetőségek száma. A gyakorlati ismeretek elsajátítása és a felsőfokú agrárképzés gyakorlatorientáltsága a rendszerváltás előtt nagy hangsúlyt kapott. Herneczky (2011) doktori munkájában NÉMETH (1979), KÁDÁRKOCSIS (1979), FELLEG (1979), LENGYEL (1979) munkáira hivatkozva említi, hogy a különbözö agrár-felsöoktatási intézményekben a gyakorlati ismeretek nélkülözhetetlenek. 
PATKÓSRA hivatkozva (2007) kifejti, hogy a rendszerváltás elötti agrárképzés egyik fö erössége a gyakorlati szakemberekkel való kiterjedt kapcsolaton alapult. Ez a szoros együttmüködés megtört a rendszerváltás után a gerincét adó nagyüzemek visszafejlödésével, ahol az együttmüködö értelmiség jelentös részét foglalkoztatták. A felsöoktatásba akkor bekapcsolódók vagy munka mellett végezték tanulmányaikat, vagy már otthonról komoly gyakorlati tudást hoztak magukkal. Azóta azonban a fiatal generációra jellemzö, hogy egyre kevesebben dolgoznak a mezőgazdaságban, egyre kevésbé szeretnék átvenni az szüleik által felépített családi gazdaságot. Sajnálatos, hogy az agrárvállalkozások többsége a mai napig csak és kizárólag a gyakorlati tapasztalatokra támaszkodik, ahol jellemezően még mindig idősebb a gazdasági irányítója. KSH (2008/b) A megfelelő szaktudás hiánya azonban jelentősen rontja a gazdaságok versenyképességet. Az agrár képzési területre bevezetett duális képzés egy jó gyakorlati lehetőséget termethet a hallgató számára, azonban a tapasztalatok szerint nagyon nagy a lemorzsolódási arány, részben a képzési időszakok rugalmatlansága miatt. A felvi.hu adatai alapán inkább az agrárszakok iránti érdeklődés rapszódikussága figyelhető meg, mely véleményünk szerint a képzési kínálat változtatásával és a duális képzés bevezetésével magyarázható. Az elkövetkezőendő években mindenképpen a duális képzés eredményességét figyelemmel kell kísérni, miként befolyásolta az agrárképzések sikerességét, és a hallgatók elhelyezkedési esélyeit.

\section{Köszönetnyilvánítás}

Köszönettel tartozunk a kutatás támogatásáért, amelyaz EFOP-3.6.1-16-2016-00006 „A kutatási potenciál fejlesztése és bővítése a Neumann János Egyetemen" pályázat keretében valósult meg. A projekt a Magyar Állam és az Európai Unió támogatásával, az Európai Szociális Alap társfinanszírozásával, a Széchenyi 2020 program keretében valósul meg.

\section{Hivatkozott források}

1. ALVINCZ J. - VARGA T. (2000): A családi gazdaságok helyzete és versenyképességük javításának lehetőségei. Agrárgazdasági tanulmányok, AKI, 15, 36-49.

2. BIRÓ Sz. - RÁCZ K. (2014): Hatékonyság és foglalkoztatás a magyar mezőgazdaságban - Hozzászólás Mészáros Sándor és Szabó Gábor vitacikkéhez. Gazdálkodás, 58(4), 376383. DOI: 10.22004/ag.econ.206099

3. DAJNOKI K. - KUN A. I. (2016): Frissdiplomások foglalkoztatásának jellemzői az agrárgazdaságban. Gazdálkodás, 60(4), 289-304. DOI: 10.22004/ag.econ.258056

4. DÓZSA G. (2017): A mezőgazdasági foglalkoztatás sajátosságai. Agrotrend Agrárgazdasági Szakportál. Forrás: https://www.agrotrend.hu/hireink/a-mezogazdasagifoglalkoztatas-sajatossagai

5. EURÓPAI BIZOTTSÁG (2017): Mezőgazdasági politika - Partnerség Európa és a gazdálkodók között. Kommunikációs Főigazgatóság (Európai Bizottság).

6. EUROPEAN COMMISSION, DIRECTORATE GENERAL FOR AGRICULTURE (2006): Studyon Employment in Rural Areas /SERA/, p. 34., 114.

7. EUROPEAN COMMISSION (2012): EU Agricultural Economic Briefs, pp. 1-10. Forrás: http://ec.europa.eu/agriculture/sites/agriculture/files/ruralareaeconomics/briefs/pdf/06_en.pdf 
8. EUROSTAT (2015): Agriculture, forestry and fishery statistics (Mezőgazdasági, erdészeti és halászati statisztikák).

9. EUROSTAT (2016): Agriculture statistics - family farming in the EU. Forrás: http://ec.europa.eu/eurostat/statistics-explained/index.php/Agriculture_statistics__family_farming_in_the_EU

10. EMBER Z. - MIHÁLOVITS A. (2007): Generációváltás az agráriumban. Ki veszi át a stafétát? Haszon Agrár, 2007/5. (szeptember - október), 14-20.

11. FELVI (2020): Elmúlt évek statisztikái. Forrás:

12. https://www.felvi.hu/felveteli/ponthatarok_statisztikak/elmult_evek/!ElmultEvek/index. php/elmult_evek_statisztikai/kepzesiteruletenkentidosorosan?filters\%5Bsta_kpt_nev\%5 $\mathrm{D}=\mathrm{agr} \% \mathrm{C} 3 \% \mathrm{~A} 1 \mathrm{r}$

13. HANTOS K. (2010): A hatékony generációváltás elősegítése a mezőgazdaságban - Fiatal gazdák támogatása. [PhD értekezés]. Budapest: Corvinus Egyetem Tájépítészeti Kar.

14. HERMAN S. - KÖRÖSPARTI P. - KÖMÍVES P. M. (2018): A magyar agrárfelsőoktatás aktuális helyzete. International Journal of Engineering and Management Sciences (IJEMS), 3(4), 263-281. DOI:10.21791/IJEMS.2018.4.23.

15. HERNECZKY A. (2011): Az agrár-felsőoktatás helyzete-jellemző tendenciák és kihívások. [PhD értekezés]. Gödöllö: Szent István Egyetem. Forrás: https://szie.hu/file/tti/archivum/Herneczky_Andrea_ertekezes.pdf

16. KAPRONCZAI I. (2007): Információs rendszerek a közös agrárpolitika szolgálatában. Budapest: Szaktudás Kiadó Ház.

17. KIEŁBASA, B. (2016): Education as a determinant of the implementation of innovation in agriculture in the light of empirical research. Roczniki Naukowe Stowarzyszenia Ekonomistów Rolnictwai Agrobiznesu, 18(1), 111-116.

18. KOMLÓSI É. (2008): Az agrárszektorban elhelyezkedni szándékozó fiatalok vizsgálata. Gazdálkodás, 52(5), 85-93.

19. KOVÁCH I. (2012): A vidék az ezredfordulón. A jelenkori magyar vidéki társadalom szerkezeti és hatalmi változásai. Budapest: Argumentum Kiadó, MTA TKSZI, pp. 4146.

20. KOVÁCS G. (2010): A mezőgazdasági szektor nemzetgazdasági jelentősége. Gazdálkodás, 54(5), 466-478. DOI: 10.22004/ag.econ.99143

21. KSH (2004) (szerk. Gizczi J. - Sághi G.): Időskorúak Magyarországon. Budapest: KSH.

22. KSH (2010): Általános Mezőgazdasági Összeírás. Forrás: https://www.ksh.hu/agrarcenzusok_amo_2010_tablak

23. KSH (2011): Népszámlálás. http://www.ksh.hu/docs/hun/xftp/idoszaki/nepsz2011/nepsz_03_00_2011.pdf

24. KSH (2015): A mezőgazdasági képzettségüek társadalmi jellemzői. p. 28. Forrás: https://www.ksh.hu/docs/hun/xftp/idoszaki/pdf/mkepzes.pdf

25. KSH (2016): Magyarország 2015. p. 185. Forrás: https://www.ksh.hu/docs/hun/xftp/idoszaki/mo/mo2015.pdf

26. KSH (2018): A mezőgazdaság szerepe a nemzetgazdaságban. Forrás: https://www.ksh.hu/docs/hun/xftp/idoszaki/mezo/mezoszerepe18.pdf. Letöltés dátuma: 2020. június 26.

27. KSH (2020): Magyarország interaktív korfája. Forrás: https://www.ksh.hu/interaktiv_korfa

28. LACZKA É. - WEISZ M. (2013): A fiatal gazdák helyzete Magyarországon. Budapest: KSH, Fiatal Gazdák Magyarországi Szövetsége.

29. LAKNER Z. (2012): Túl sok agrárszakembert képzünk?. Gazdálkodás, 56(1), 66-74. DOI: $10.22004 /$ ag.econ.141804 
30. MATKÓ A.- TAKÁCS T. - BAKSI Zs. (2015): Innovation over view of the Northern Plains Region. Annals of the Oradea University - Fascicle of Management and Technological Engineering, XXIV(XIV), 133-136. DOI:10.15660/AUOFMTE.20151.13093

31. MÉSZÁROS S. - SZABÓ G. (2014): Hatékonyság és foglalkoztatás a magyar mezőgazdaságban. Gazdálkodás, 58(1), 58-74. DOI: 10.22004/ag.econ.201227

32. POPP J. - LAKNER Z. - HARANGI-RÁKOS M. - FÁRI M. (2014): The effect of bioenergy expansion: Food, energy and environment. Renewable and Sustainable Energy Reviews, 32, 559-578. DOI:10.1016/j.rser.2014.01.056

33. POPP J. (2014): Hatékonyság és foglalkoztatás a magyar mezőgazdaságban. Gazdálkodás, 58(2), 173-184. DOI: 10.22004/ag.econ.201403

34. POPP J. - HARANGI-RÁKOS M. - GABNAI Z. - BALOGH P. - ANTAL G. - BAIA. (2016): Biofuels and Their Co-Products as Livestock Feed: Global Economic and Environmental Implications. Molecules, 21(3), 285, 1-26. DOI: 10.3390/molecules21030285

35. SZÉKELY E. (2009): Nemzedékváltás a mezögazdaságban. Budapest: Agrárközgazdasági Intézet.

36. SZÜCS Cs. - ZÖRÖG Z. (2013): Agrárdiplomások helyzete a munkaerőpiacon. Gazdálkodás 57(6). 588-597. DOI: 10.22004/ag.econ.199968

\section{Szerző(k):}

\section{Finta Zita}

föigazgató helyettes

Nemzeti Közszolgálati Egyetem Campus Igazgatóság

1083 Budapest Ludovika tér 2.

finta.zita@uni-nke.hu

\section{Dr. Palkovics András PhD}

dékán, egyetemi docens

Neumann János Egyetem

Kertészeti és Vidékfejlesztési Kar Agrárökonómiai és Vidékfejlesztési Tanszék 6000 Kecskemét Izsáki út 10.

palkovics.andras@kvk.uni-neumann.hu

\section{Dr. Köszegi Irén Rita PhD}

adjunktus

Neumann János Egyetem

Kertészeti és Vidékfejlesztési Kar Agrárökonómiai és Vidékfejlesztési Tanszék

6000 Kecskemét Izsáki út 10.

koszegi.iren@kvk.uni-neumann.hu 